\title{
Interpreting the Meaning of Lender Management Participation Under Section 101(20)(A) of CERCLA
}

\author{
Roslyn Tom
}

The magnitude of the nation's hazardous waste problem is staggering. ${ }^{1}$ To provide broad federal authority to prevent or remedy releases of hazardous substances from the growing number of abandoned sites, Congress enacted in 1980 the Comprehensive Environmental Response, Compensation, and Liability Act (GERCLA). ${ }^{2}$ The Act created a $\$ 1.6$ billion "Superfund" 3 that enabled the government to clean up contaminated sites and that authorized it to hold parties responsible for cleanup costs. The 1986 Superfund Amendments and Reauthorization Act (SARA) ${ }^{5}$ provided an $\$ 8.5$ billion replenishment to address the increasing number of potential Superfund sites. ${ }^{6}$ Courts have construed CERGLA to impose strict, ${ }^{7}$ joint and several, ${ }^{8}$ and retroactive ${ }^{8}$ liability on responsible parties. They also have restricted the use of the affirmative defenses provided by GERGLA. ${ }^{10}$

An "owner or operator" of a facility is a potentially responsible party under GERCLA's liability provisions. The term "owner or operator"

1. See, e.g., Superfund: Looking Back, Looking Ahead, EPA J., Jan.-Feb. 1987, at 13, 17 (estimating that United States had roughly 9,000 problem hazardous waste sites in 1980).

2. Pub. L. No. 96-510, 94 Stat. 2767 (1980) (codified in part as amended at 42 U.S.C. $\S \S 9601-9657$ (1982 \& Supp. IV 1986)). Congress defines "hazardous substance" at 42 U.S.C. $\S 9601$ (14) (Supp. IV 1986).

3. 42 U.S.C. § 9631 (1982) (current version at 26 U.S.C. § 9507 (Supp. IV 1986)).

4. CERCLA defines responsible parties as present and past owners or operators of contaminated sites, generators of hazardous substances sent to such sites, and transporters of hazardous substances who selected such sites. 42 U.S.C. $\$$ 9607(a)(1)-(4) (Supp. IV 1986). To recover costs from these parties, the government must establish that the site is a facility from which a release or threatened release of any hazardous substance occurred that caused the United States to incur response costs. $I d$.

5. Pub. L. No. 99-499, 100 Stat. 1613 (1986) (codified in part at 42 U.S.C. $\$ \S 9601-9675$ (Supp. IV 1986)).

6. The United States General Accounting Office has found as many as 425,380 potential Superfund sites. See 18 Env't Rep. (BNA) 2043 (Jan. 22, 1988). Corrective action for only 2,500 of these could cost more than $\$ 22$ billion. Id.

7. See, e.g., New York v. Shore Realty Corp., 759 F.2d 1032, 1042 (2d Cir. 1985).

8. See, e.g., United States v. Chem-Dyne Corp., 572 F. Supp. 802, 811 (S.D. Ohio 1983).

9. See, e.g., United States v. Shell Oil Co., 605 F. Supp. 1064, 1072-73 (D. Colo. 1985).

10. See, e.g., Shore Realty Corp., 759 F.2d at 1048-49 (third-party defense denied to defendant). 42 U.S.C. $\S 9607$ (b)(3) (Supp. IV 1986) provides a third-party defense to liability where the defendant establishes that the release or threatened release was caused solely by an act or omission of a third party other than one whose act or omission occurs in connection with a contractual relationship. 
means "in the case of [a] . . f facility, any person owning or operating such facility .... Such term does not include a person, who, without participating in the management of a vessel or facility, holds indicia of ownership primarily to protect his security interest in the vessel or facility."11 Thus, Congress provided an exception to liability as an "owner or operator" of a contaminated site for persons, such as financial institutions, who hold "indicia of ownership" to protect their security interests and who do not "participat[e] in the management" of the sites. Because CERCLA was hastily drafted and adopted, with resulting ambiguities left unclarified by the sparse legislative history, ${ }^{12}$ it is unclear when lenders hold "indicia of ownership" and have not "participated in [ ] management" to be protected under the above "security interest exemption."13

SARA indicates that Congress intended to hold a mortgagee who forecloses on a contaminated site liable for cleanup costs as the fee owner of the property. ${ }^{14}$ By barring protection under the security interest exemption to foreclosing mortgagees, Congress attempted to encourage banks to investigate before lending to parties who handle hazardous wastes. ${ }^{15}$ Accordingly, banks would then also monitor the debtor's site during the loan period to avoid holding an interest in contaminated collateral. ${ }^{16}$

11. 42 U.S.C. $\$ 9601(20)$ (A) (Supp. IV 1986).

12. See 126 Cong. REc. 31,969 (1980) (statement of Rep. Broyhill).

13. In describing the exemption to liability as an "owner," the legislative history states:

[The term "owner"] does not include certain persons possessing indicia of ownership (such as a financial institution) who, without participating in the management or operation of a vessel or facility, hold title either in order to secure a loan or in connection with a lease financing arrangement under the appropriate banking laws, rules, or regulations. ... [A] financial institution which held title primarily to secure a loan but also received tax benefits as the result of holding title would not be an "owner" as long as it did not participate in the management or operation of the vessel or facility.

H.R. ReP. No. 172, 96th Cong., 2d Sess., pt. 1, at 36, reprinted in 1980 U.S. CodE Cong. \& ADMIN. NEws 6160, 6181 .

14. In 1986, Congress amended the term "owner or operator" to exclude from liability state or local governments that "acquired ownership or control involuntarily through bankruptcy, tax delinquency, abandonment," or similar means, 42 U.S.C. $\S 9601(20)(D)$ (Supp. IV 1986), and to hold liable "any person who owned, operated, or otherwise controlled activities at [the] facility immediately beforehand," 42 U.S.C. $\S 9601$ (20)(A) (Supp. IV 1986). The fact that Congress did not at the same time amend the term also to exclude from liability lenders who acquire property through foreclosure indicates that it intended to hold them liable as owners. See Vollmann, Double Jeopardy: Lender Liability Under Superfund, 16 ReAL EST. L.J. 3, 11 (1987).

15. For example, 42 U.S.C. $\$ 9601(35)(A)$-(B) (Supp. IV 1986) provides an "innocent landowner" defense that works in tandem with the third-party defense to protect owners who did not know or had no reason to know the site was contaminated at the time of purchase. Because the "due diligence" standards that defendants must exercise under this provision to discover whether a site is contaminated are extremely rigorous for commercial entities, the defense acts in effect as a means of creating incentives for safer waste handling and disposal. See Brandt, Contaminated Collateral: A New Subspecialty, AM. LAw., Oct. 1986, at 10 (upshot of innocent landowner provision is to encourage foreclosing mortgagees to conduct more environmental audits).

16. A bank may avoid liability as an owner by not foreclosing on a polluted site if the cleanup costs exceed the value of the collateral, thereby losing only the value of the collateral. It also may foreclose after government cleanup; however, a federal lien for reimbursement will encumber the property. 42 U.S.C. $\S 9607(l)$ (Supp. IV 1986). Moreover, if the lender forecloses on a site, and thus becomes an owner, it is obligated under 42 U.S.C. $\$ 9601(35)(C)$ to inform subsequent purchasers of environmental problems that occurred at the site. Thus, the lender may face great difficulty in selling 
CERCLA and SARA, however, leave lenders uncertain as to how much participation is required before a lender loses protection under the security interest exemption. A lender's control over a site's operations short of foreclosure could lead to liability as an operator. Congress did not elaborate on the meaning of "participating in the management" in the security interest exemption or in legislative history. ${ }^{17}$ Courts have not yet developed a predictable method of determining when lenders will be liable as operators under GERCLA. ${ }^{18}$ Liability for cleanup costs could run to hundreds of thousands of dollars and exceed the amount of the loan. ${ }^{19}$ Without clear standards defining the degree of control a lender can safely exercise over the debtor's operations, banks will be deterred from monitoring sites. ${ }^{20}$

Yet banks could greatly advance CERCLA's goals, particularly that of safe waste disposal, by assisting financially troubled debtors with potential environmental problems. Wary that they could hold contaminated collateral and be liable as the owner of a facility if they foreclose, banks already have been investigating debtors' sites before lending. ${ }^{21}$ Although society benefits when banks examine facilities before lending, it can further benefit from the monitoring role that banks normally play during the loan term. For example, banks can examine the potential liability and solvency of a debtor with environmental problems, suggest that it hire experts to solve them, and disburse the funds needed to work them out, rather than declare a default hastily. But if lenders are unable to predict the scope of potential liability they may incur as constructive operators of the site, they

property encumbered with a lien for cleanup costs.

17. Congress, however, did comment on the meaning of "operator" in the legislative history. This sheds light on the minimum that could be meant by "participating in the management," since management participation would apply only to deny a lender protection under the security interest exemption where liability as an operator was already established. See infra notes 59-61 and accompanying text.

18. See United States v. Mirabile, 15 Envtl. L. Rep. (Envtl. L. Inst.) 20,994, 20,995 (E.D. Pa. 1985) ("difficulty arises ... in determining how far a secured creditor may go in protecting its financial interests before it can be said to have acted as an owner or operator within the meaning of [CERCLA]").

19. See, e.g., United States' Memorandum in Support of Its Second Motion for Leave to Amend Complaint at 19, United States v. Nicolet, No. 85-3060 (E.D. Pa. filed Nov. 22, 1988) (parent company/mortgagee being sued for $\$ 2.5$ million in response costs); United States v. Maryland Bank \& Trust Co., 632 F. Supp. 573, 575-76, 582 (D. Md. 1986) (cleanup costs exceeded outstanding loan).

20. See Burcat, Foreclosure and United States v. Maryland Bank \& Trust Co.: Paying the Piper or Learning How to Dance to a New Tune?, 17 Envtl. L. Rep. (Envtl. L. Inst.) 10,098, 10,099 (1987) (banks will avoid assisting debtors whose sites are connected with hazardous waste activity for fear of CERCLA liability); Chang, Toxic Waste Worries Grow Among Lenders, Regulators, Mortgage Commentary, Aug. 19, 1988, at 1 (noting irony that the more lenders do to prevent contamination of properties to which they hold liens, the more likely they are to be stuck with bill).

21. See, e.g., Flagg, Toxic Waste Pockets Make Property Buyers Step Carefully; Costly Surprises May Lurk in Buildings, Underground, L.A. Times, Aug. 28, 1988, $\S 4$ (Business), at 7, col. 1 (to satisfy lenders, developers must go through "incredible hoops" to buy piece of property); Crain, Toxic Cleanup Liability Forces Lenders to Tighten Up, Den. Bus. J., June 6, 1988, $\$ 1$, at 15 (lenders are playing larger role in society, and are police force for hazardous materials; they are writing into loan commitments mandatory environmental audits and extensive ownership and usage histories on all commercial properties under financing consideration). 
will refrain from aiding borrowers; moreover, they may simply choose not to lend. ${ }^{22}$ Without capital, businesses cannot afford to implement the waste reduction practices necessary to protect public health and the environment. ${ }^{23}$

A narrow interpretation of the phrase "participating in the management" in the security interest exemption could encourage banks to monitor waste sites. Such an interpretation would benefit both banks and society: Banks would be more willing to engage in workouts to recover loans and thus would be more likely to ensure that small waste problems do not increase; at the same time, society would benefit because banks could help prevent future environmental harms through diligent monitoring. A broad construction of management participation, though consistent with the expansive interpretations generally given to CERCLA's liability provisions, would be short-sighted. It would discourage banks from monitoring and deprive society of further benefits that banks could provide during the loan term. ${ }^{24}$ Moreover, a policy of imposing liability on banks because they are "deep pockets" is not supported by the statute, which explicitly exempts secured creditors from liability under certain conditions. ${ }^{25}$

This Note proposes that courts applying CERCLA look to guidelines developed under analogous doctrines of lender liability in order to give shape to the scope of permissible involvement by banks in the activities of their borrowers. Section I sets out the current liability standards, discusses the need to develop the meaning of management participation to encourage monitoring, and explains why lenders are effective at monitoring their borrowers' environmental health. Section II provides a framework for interpreting the meaning of management participation by reference to the doctrines of equitable subordination and alter ego. ${ }^{26}$ Through a cumulative test approach-a standard that looks to total domination rather than to a checklist of actions-these established doctrines can provide certainty by depicting the circumstances that have and have not led to findings of lender management control. With the confidence that they will not be held

22. See Burcat, Environmental Liability of Creditors: Open Season on Banks, Creditors, and Other Deep Pockets, 103 Banking L.J. 509, 539 (1986); Business Operators Advised to Take Notice of Liability Under Environmental Regulations, 18 Env't Rep. (BNA) 445 (May 22, 1987) (quoting Thomas M. McMahon, Chicago attorney).

23. U.S. Gen. Accounting Office, Hazardous Waste: Issues Surrounding Insurance Availability 31 (Oct. 1987).

24. See Comment, The Liability of Financial Institutions for Hazardous Waste Cleanup Costs Under CERCLA, 1988 WIS. L. REv. 139, 180-81 (if courts could give narrower reading to term "management," lenders could influence borrowers' hazardous waste activities, a result more beneficial to lender, borrower, and society).

25. This has been recognized judicially. See United States v. Mirabile, 15 Envtl. L. Rep. (Envtl. L. Inst.) $20,994,20,996$ (E.D. Pa. 1985).

26. Courts have interpreted CERCLA to impose strict, joint and several, and retroactive liability. See supra notes 7-9 and accompanying text. Thus, common law standards can be used to construe management participation. Burcat, supra note 22 , at 528-31, 533, also notes the potential utility of atter ego doctrine and agency law principles. 
responsible for their borrowers' waste disposal practices under certain circumstances, banks will have a stronger incentive to lend prudently and to monitor diligently during the loan period, thereby advancing the goals of GERCLA.

\section{LeNDERS AS Operators UNDER GERGLA}

\section{A. Current Liability Standards}

Only one case so far has substantively addressed the problem of interpreting the term "participating in the management" under the security interest exemption. ${ }^{27}$ In United States $v$. Mirabile, the court held on motions for summary judgment that a hazardous waste site owner's secured creditors, including one who foreclosed on the site, could be held liable for response costs only if they were involved in the facility's operational, production, or waste disposal activities. ${ }^{28}$ The court did not construe "participating in the management" literally, but distinguished financial decisionmaking from it. Mirabile defined the financial ability to control business practices as management of the affairs of the site's actual owner or operator, ${ }^{28}$ the exercise of which would not give rise to GERGLA liability. The court did not explain exactly what constituted management participation and financial control, but discussed the activities of the three creditor de-

27. Mirabile, 15 Envtl. L. Rep. (Envtl. L. Inst.) at 20,994. For a discussion of one case that recently commented on lender management participation under CERCLA, see infra note 32 . In In re T.P. Long Chemical Inc., 45 Bankr. 278, 288-89 (Bankr. N.D. Ohio 1985), another lender liability case, the court found that the secured creditor had been totally removed from management, and therefore did not discuss the meaning of management participation under CERCLA. United States v. Maryland Bank \& Trust Co., 632 F. Supp. 573 (D. Md. 1986), focused on whether a foreclosing mortgagee was an owner of the site, but did not consider how a lender could be deemed an operator.

There have been few lender liability cases so far, mainly because the federal government has not pursued banks as a class the way it has pursued other potentially responsible parties listed under CERCLA's liability provisions. The government will bring an action against a bank when it believes that it has a valid reason and that the law is on its side: for example, when a problem site exists, the actual owner or operator cannot be found or is insolvent, the bank can be found and is solvent, and the bank acted in a way that could make it liable under CERCLA. For example, the Department of Justice has sued a lienholder of the assets of a bankrupt cloth printing company for response costs incurred, alleging that the secured lender controlled the company after the plant had already closed and thus is liable as an "owner or operator" when asbestos was released during the liquidation of assets. United States v. Fleet Factors Corp., No. 687-070, order at 12-13 (S.D. Ga. Dec. 22, 1988) (denying cross-motions for summary judgment by United States and Fleet Factors); see infra note 32 (discussing interpretation of management participation by court in Fleet Factors). See also United States' Memorandum in Support of Its Second Motion for Leave to Amend Complaint at 10, 18, United States v. Nicolet, Inc., No. 85-3060 (E.D. Pa. filed Nov. 22, 1988) (alleging that mortgagee, who is also former corporate parent of polluter, is liable as owner or operator); $c f$. Coastal Casting Serv., Inc. v. Aron, No. H-86-4463 (S.D. Tex. Apr. 8, 1988) (WESTLAW, Allfeds database) (present owner/operator alleging that lender is responsible for cleanup as past owner/operator; lender's motion to dismiss denied to permit discovery). The lack of a predictable standard may result in increased litigation on the issue of management participation and may deter banks who are still in active relationships with their debtors from monitoring sites and encouraging safe disposal practices.

28. 15 Envtl. L. Rep. (Envtl. L. Inst.) at 20,995.

29. Id. at $20,995-96$. 
fendants and whether those activities could be considered management participation..$^{30}$

Using principles of financial control and management participation, the court found that the activities of the foreclosing mortgagee, which had secured a building on the debtor's site against vandalism, inquired about the cost of disposing the property's drums, and visited the site occasionally to show it to prospective purchasers, were prudent and routine steps to secure the property against further depreciation. ${ }^{31}$ On the other hand, the court denied the other secured creditor's motion for summary judgment, stating that a genuine issue of fact existed as to whether the bank agent who was on the debtor's advisory board engaged in the sort of management participation that would bring the bank within the scope of CERGLA liability. It also suggested that insistence on certain manufacturing changes, reassignment of personnel, demand for additional sales efforts, determining the order in which orders were filled, and weekly site visitations might be characterized as involvement in the site's "day-to-day operations." 32

Although Mirabile's result appears reasonable, the court's fact-based approach does not provide the predictability banks need to continue to lend. A strict liability approach for banks could provide such certainty, but would be inconsistent with the purposes of the statute: Banks cannot be potentially responsible parties unless they are owners or operators.

30. For instance, one bank described its involvement as "monitoring the cash collateral accounts, ensuring that receivables went to the proper account, and establishing a reporting system between the company and the bank." Id. at 20,997. The court reasoned that "this sort of activity would not give rise to CERCLA liability." Id. Because the debtor, a paint manufacturing company, disposed of hazardous wastes as an incident to its business operations, the court also limited its ruling "to financial institutions which provide funds to entities which dispose of hazardous wastes as a result of their business operations." Id. at 20,996 n.5.

31. The court also exempted from liability a secured creditor that provided "management assistance" including frequent visitations to the site to monitor liquidation of assets, required creditor approval prior to execution of contracts for management consulting services, and restricted certain financial dealings. Id. at 20,996. Because the secured creditor was the Small Business Administration, it is uncertain whether the court would have ruled the same way were the creditor not a government entity.

32. Id. at 20,997. In denying cross-motions for summary judgment in Fleet Factors, Judge Bowen stated:

I interpret the phrases "participating in the management of a . . f facility" and "primarily to protect his security interest," to permit secured creditors to provide financial assistance and general, and even isolated instances of specific, management advice to its debtors without risking CERCLA liability if the secured creditor does not participate in the day-to-day management of the business or facility either before or after the business ceases operation.

United States v. Fleet Factors Corp., No. 687-070, order at 10 (S.D. Ga. Dec. 22, 1988) (emphasis in original).

Although the court could not extensively comment on what specific lender activities would constitute management participation, its judgment does support the propositions set forth in Mirabile. For instance, it found that the secured lender's pre-auction activities-refusing to advance additional funds because of an overadvanced account, collecting accounts receivable assigned to it, and checking on the credit of the debtor's customers before shipment of goods-did not rise to the level of participation in management to impose CERCLA liability. The disputed facts as to whether the lender was an "owner or operator" when asbestos was alleged to have been released during the liquidation of assets led the court to deny cross-motions for summary judgment by the United States and the lender. 
Moreover, a broad liability standard would undermine CERCLA's goal of preventing future harm to the environment, as banks would be deterred from monitoring debtors involved in hazardous waste management.

\section{B. The Need to Encourage Monitoring}

Because a goal of CERCLA is to promote safe hazardous waste handling and disposal, courts should interpret the statute in a way that does not discourage banks from deterring reckless disposal practices. To encourage banks to become monitors, courts should adopt a high and predictable threshold of liability for banks. ${ }^{33}$ Under a low liability threshold, the lender would quickly sever its relationship with a financially distressed debtor, accelerate loan payments, and try to recover the debt. ${ }^{34}$ Under such a scenario, all parties are worse off: the debtor cannot afford to dispose of wastes properly, the lender may not fully recover the loan, and the environment will suffer until the government shoulders the cleanup costs. Such a result is precisely what CERCLA's liability provisions are designed to avoid. ${ }^{35}$

\section{Lenders as Quasi-EPA Monitors}

This Note argues that lenders are effective monitors of the environmental health of their debtors. Expertise and the ability to spread risks are considerations that determine which parties make effective monitors. ${ }^{36}$ Lenders, insurance companies, and the federal government are the possible candidates to monitor hazardous waste sites. Of the three, lenders are optimal because they have both the expertise to monitor the economic and environmental health of their debtors and the ability to spread the risks of cleanup costs. Although debtors are better risk avoiders because they can mitigate or prevent hazardous waste releases at the lowest cost, lenders, who are risk-averse, can insure against the risk more efficiently.

First, lenders are expert monitors: It is their business, and it furthers their interests, to collect information about debtors' operations before lend-

33. A low threshold of liability also could provide predictability, but is undesirable because banks would be deterred from monitoring the environmental health of their debtors. See supra note 24 and accompanying text.

34. See, e.g., Soriano \& Lockett, Hazardous Waste Liability: The Emerging Problem for Lendets, 12 Chem. WASTE LrTigation REP. 47, 59 (1986) (current liability interpretation may force lenders to push borrowers handling hazardous wastes into bankruptcy rather than risk potential liability by engaging in normal workouts).

35. See Note, When a Security Becomes a Liability: Claims Against Lenders in Hazardous Waste Cleanup, 38 Hastings L.J. 1261, 1295 (1987) (ambiguity of "participating in the management" term will impede lenders who wish to monitor debtor's use of security property; this result conflicts with CERCLA's purpose of encouraging private parties to involve themselves in safer waste disposal and to assist debtors in cleaning up hazardous wastes); see supra notes $20 \& 22$ and accompanying text.

36. In G. Calabresi, The Costs of Accidents 35-129 (1970), the author suggests that the party who can most cheaply avoid costs should be the one to bear the risk of loss. When parties are risk-averse, the party best able to bear or to insure against the risk should be held liable. 
ing, to monitor investments, and to police debtors' activities in order to protect their collateral. ${ }^{37}$ They bargain for these privileges through loan agreement covenants. ${ }^{38}$ Banks do not monitor technical decisions involving pollution by examining fluids and discharges, in which banks are presumably unskilled, but rather examine the economic and environmental health of the company through loan covenants, in which banks are experienced. Therefore, they can be effective overseers. ${ }^{39}$

Second, lenders are efficient risk spreaders. They assume the costs of monitoring their investment through interest rates, ${ }^{40}$ and transfer to borrowers the costs of pre-loan audits. Lenders will prefer to bear the risk of loss ${ }^{41}$ and ensure against "releases or threatened releases" of hazardous substances to satisfy due diligence requirements under the innocent landowner defense. ${ }^{42}$ If debtors bore the risk of cleanup costs, lenders would still assume the risk that the debtor might underinsure or become insolvent. ${ }^{43}$ Unless borrowers can get lower rates themselves, they will be indifferent towards paying the higher interest rates or transactions costs that lenders will charge to bear the risk of loss, since the borrowers would have had to insure against the risk in any event, perhaps at a higher price, ${ }^{44}$ if banks did not do so. ${ }^{45}$

37. See generally Levmore, Monitors and Freeriders in Commercial and Corporate Settings, 92 YALE L.J. 49, 56 (1982) (commercial bank has excellent monitoring ability); Schwartz, Security Interests and Bankruptcy Priorities: A Review of Current Theories, $10 \mathrm{~J}$. Legal STud. 1, 11 n.28 (1981) (bank can learn of important changes in debtor's affairs).

38. See Simpson, The Drafting of Loan Agreements: A Borrower's Viewpoint, 28 Bus. Law. $1161,1177-88$ (1973) (function of restrictive loan covenants is to maintain or improve ratio between debt and assets that exists at time financing extended). Through covenants, lenders can require borrowers to conduct environmental audits to ensure that no contamination problems exist; submit copies of notices received on environmental law violations or commencement of litigation; notify the lenders of significant changes in the use or operations of the property that may have an environmental impact; and clean up hazardous substances upon discovery. Kane \& Morrel, Environmental Risk Management, Secured Lender, Sept.-Oct. 1986, at 23, 26; see also Cahan, Environmental Wastes: The New Risk in Secured Lending, Lending FOR COM. B.ANkER, Summer 1987, at 32, 38.

39. Cf. Comment, The Impact of the 1986 Superfund Amendments and Reauthorization Act on the Commercial Lending Industry: A Critical Assessment, 41 U. MÍAMI L. Rev. 879, 902 (1987) (comprehensive national monitoring program not economically feasible undertaking for lenders; even if feasible, CERCLA liability scheme discourages them from serving as monitors).

40. See, e.g., Jackson \& Kronman, Secured Financing and Priorities Among Creditors, 88 YALE L.J. 1143, 1151 (1979) (since interest is price bank charges for use of its money, bank will raise interest rate to cover increased lending expenses).

41. To avoid duplicating monitoring costs, the lender and borrower will bargain to place the risk of loss on the party better able to bear or to insure against the risk. See supra note 36.

42. See, e.g., Climate for Real Estate Lawyers 'Gloomy' Due to Environmental Liability, $A B A$ Told, 18 Env't Rep. (BNA) 1106 (Aug. 21, 1987) (lenders should investigate sites themselves to limit risks and to help themselves in potential court defense).

43. See Schwartz, Products Liability, Corporate Structure, and Bankruptcy: Toxic Substances and the Remote Risk Relationship, 14 J. LEGAL STud. 689, 706-11, 718-19 (1985) (firms lack incentive to insure fully when risks unknowable and liability exposure greatly exceeds their wealth).

44. See infra note 49 and accompanying text (high cost of insurance).

45. Smaller banks, such as savings and loans, could also monitor and spread risks, although their ability to do so would vary directly with their size. See Levmore, supra note 37 , at 56 n.30. Smaller banks could still study a company's entire business plans and operations before lending, and obtain and evaluate information about a debtor's post-loan behavior. See Schwartz, supra note 37, at 11 n.28. The expected monitoring costs of any creditor, large or small, would vary inversely with the 
Lenders are better monitors than the federal government and insurance companies. Although the federal government effectively spreads risks through taxation, the Superfund budget is limited. ${ }^{46}$ Also, the work of the Environmental Protection Agency (EPA) focuses primarily on response actions, and identification and preliminary assessments of potentially dangerous hazardous waste sites that will need Fund-financed cleanup efforts. The EPA budget for Superfund enforcement activities for 1989 is only $\$ 10.3$ million. ${ }^{47}$ Accordingly, the EPA is limited in its monitoring capabilities. Even if it had the budget and personnel to oversee the thousands of potential Superfund sites across the country, its ability to organize itself to monitor effectively is doubtful..$^{8}$ Finally, the EPA does not have the informational advantages that lenders have in monitoring particular properties to ensure compliance with environmental statutes and regulations. Because of the close debtor-creditor relationship, the lender can better help rescue debtors from potential environmental problems, while the EPA focuses on sites in need of cleanup.

Insurance companies can be effective monitors because they spread risks through premiums and are experts in collecting and evaluating information about the insured. Insurance for environmental liability, however, is expensive and difficult to obtain..$^{48}$ Moreover, if lenders are to have debtors obtain insurance, they still assume the risk that debtors will misbehave, ${ }^{50}$ become insolvent, or underinsure. ${ }^{51}$

informational advantage the creditor has in assessing a debtor's behavior. See Jackson \& Kronman, supra note 40, at 1159-61 \& n.62. The costs of monitoring would be passed on to the debtor, since the debtor would pay the lender for the benefit of being monitored.

Levmore observes that in a two-party transaction, the lender will monitor "as long as his cost of doing so is less than his expected benefit." Levmore, supra note 37, at 49. When many potential lenders/monitors exist, with overlapping interests, the problem of "freeriding"-whereby one lender will seek to reduce monitoring costs by relying on the efforts of others-could lead to undermonitoring. Also, overlapping interests could lead to duplicative efforts, and thus overmonitoring. Id.

46. Environmental Protection Agency, Summary of the 1989 Budget 5 (1988) (1989 Superfund budget estimated at $\$ 1.7$ billion).

47. Id. at 58 (EPA expects to oversee " 70 remedial design and 35 remedial actions conducted by [responsible parties.]").

48. See, e.g., OTA Blames Superfund Problems on Management as House Subcommittee Plans to Review Program, 19 Env't Rep. (BNA) 219 (June 17, 1988) (congressional study criticizes EPA's management capabilities); Office of Technology Assessment Pans EPA for 'Inefficient' Implementation of Superfund, 18 Env't Rep. (BNA) 2524, 2524-25 (Apr. 22, 1988) ("biggest cross-cutting problem facing superfund implementation ... is a workforce which is largely inexperienced, untrained, and characterized by high turnover rates . . . little incentive exists at EPA to produce quality work and there is minimal quality assurance"); see also EPA Inspector General's Office Superfund Audit Finds Poor Work by States, Little EPA Oversight, 19 Env't Rep. (BNA) 379 (July 22, 1988) (EPA regional offices have not adequately monitored Superfund cleanups performed by states under cooperative agreements with EPA).

49. See, e.g., U.S. Gen. Accounting OFfice, supra note 23, at 12, 28, 40 (insurers maintain that inability to predict losses has made pollution risks uninsurable; many treatment, storage, and disposal facilities and generators are operating without insurance).

50. See Jackson \& Kronman, supra note 40 , at $1150-51$ n.36 ("insuring against the danger of debtor misbehavior does nothing, by itself, to reduce the likelihood of its occurrence" and does not impinge on creditor's incentive to monitor) (emphasis in original).

51. Lenders also assume the risk that courts will interpret the insurance contract in favor of the insurance company so that a financially troubled debtor may end up bearing all cleanup costs. See 


\section{A Proposed Standard to Interpret the Meaning of Management Participation}

\section{A. Selecting an Existing Standard to Serve as a Guide}

Given that certainty is required to encourage lenders to monitor the waste sites of their debtors, ${ }^{52}$ courts should look to existing lender liability standards to give shape to the meaning of "participating in the management" under CERCLA. Of the various lender liability doctrines available, those dealing with a lender's "control" of its borrower are appropriate in determining the extent to which the lender may monitor the site of its debtor. ${ }^{53}$ Equitable subordination and alter ego $^{54}$ are the preferred doctrines involving lender control to provide such a standard to interpret management participation. ${ }^{55}$ First, the doctrines provide reasonable cer-

U.S. Gen. Accounting OfFice, supra note 23, at 54-73 (contract interpretation of pollution coverage limits unsettled).

52. Clarity of legal standards is one factor that affects a lender's decision to extend credit and to monitor; magnitude of liability is another. The latter, however, is difficult to assess because environmental audits produce inherent uncertainties. See Cahan, supra note 38 , at 37 .

53. Those theories involving good faith, or lack thereof, do not accurately represent the relationship between lender and borrower contemplated in interpreting lender management participation under CERCLA. Those theories are less immediately applicable than "control" theories because they focus on whether banks were deceptive or dishonest when exercising rights under loan agreements. See, e.g., Tyler, Emerging Theories of Lender Liability in Texas, 24 Hous. L. REv. 411, 413-31 (1987) (discussing expanding duty of good faith). For example, cases under the holder-in-due-course doctrine often involve unconscionable credit contracts and waiver of defense clauses with respect to consumer purchasers. See McDonnell, Freedom from Claims and Defenses: A Study in Judicial Activism Under the Uniform Commercial Code, 17 GA. L. REv. 569, 600-08 (1983) (discussing good faith and notice under holder-in-due-course doctrine). Thus the analysis of whether the third-party financier and seller were sufficiently "closely connected" to be a single enterprise under the holder-indue-course theory, so that the financier would be liable for losses resulting from the seller's misconduct, does not serve as an appropriate framework to discern the scope of management participation under CERCLA.

This is not to say that banks liable under "control" theories cannot be liable under doctrines involving fair play. See, e.g., State Nat'l Bank v. Farah Mfg. Co., 678 S.W.2d 661 (Tex. Ct. App. 1984) (corporate debtor establishes cause of action for damages against creditors for fraud and duress as well as interference with business relations). Also, lenders not liable under a "control" theory could be liable for lack of good faith. See, e.g., K.M.C. Co. v. Irving Trust Co., 757 F.2d 752 (6th Cir. 1985) (lender's power to demand repayment under financing agreement provision limited by obligation of good faith, even though indebtedness payable on demand). This Note, however, focuses on a standard for interpreting the ambiguous phrase, "participating in the management," and thus primarily requires an examination of lender "control" theories-whereby the "exercise of control over the day to day operations or management of a borrower . . . can result in legal consequences." Tyler, supra, at 431.

54. Equitable subordination applies to bankruptcy proceedings in which creditors of the debtor request the court to subordinate the claim of a dominating creditor that engaged in inequitable conduct. Creditors also may request that courts use the doctrine of alter ego to pierce the corporate veil of an insolvent company controlled by a lender to satisfy creditors' claims.

55. Other lender "control" theories, such as agency, tortious interference, and limited partnership, are less applicable as a standard to interpret management participation under CERCLA. Agency theory does not seem appropriate because cases applying it usually involve trade creditors; thus it is easier to find common interests and identity of goals between the principal and the agent. See, e.g., A. Gay Jenson Farms Co. v. Cargill, Inc., 309 N.W.2d 285 (Minn. 1981) (agency relationship established between grain dealer and local grain elevator). The theory of tortious interference does not provide the certainty that a standard for interpreting management participation needs. See Note, $E q$ uitable Subordination and Analogous Theories of Lender Liability: Toward a New Model of "Control," 65 TEx. L. REv. 801, 844 (1987) ("tortious interference has not yet 'developed a crystallized 
tainty since they have been applied consistently by courts. ${ }^{56}$ Second, the doctrines are appropriate in determining the scope of management participation because they have been applied to cases drawing the gray line between a lender's legitimate management of a loan and its excessive control of the borrower's activities. Cases under these doctrines reveal both consistent fact patterns that have been considered appropriate lender behavior and activities that have led courts to find a control relationship in which the creditor dominated the debtor. Because a lender generally does not wish to operate the debtor's business, ${ }^{57}$ but may take steps to protect its loan when the debtor experiences financial difficulties, courts will invoke the doctrine of equitable subordination or alter ego if they find that the lender exercised control that amounted to total domination of the debtor.

\section{B. Total Domination as an Available Interpretation}

Although a standard of total domination appears to be more restrictive than a literal interpretation of the words "participating in the management," an approach that looks to the lender's cumulative behavior by focusing on total control is a plausible method of construing management participation. Because legislative history does not provide any clues on what lender activities constitute management participation, and confusion exists concerning what lenders can do without "participating in the management," the term is ambiguous and thus open to a variety of interpretations.

First, a construction of total control is consistent with, and advances, Congress' goal of encouraging private parties to engage in surveillance of pollution conditions and safer disposal practices. ${ }^{58}$

Second, because a lender whose activities constitute "participating in the management" of the facility under the statute would incur liability as an operator, the security interest exemption only makes sense if manage-

set of definite rules" "). The doctrine of limited partnership also does not provide the certainty this standard requires. See Basile, Limited Liability for Limited Partners: An Argument for the Abolition of the Control Rule, 38 VAND. L. REv. 1199, 1221 (1985) ("Both academicians and practitioners have bemoaned the control rule's inherent uncertainty."). The small number of cases involving the liability of lenders of construction loans have not provided clear rules for developing a standard. Compare Smith v. Continental Bank, 130 Ariz. 320, 636 P.2d 98 (1981) (no bank liability) with Connor v. Great W. Sav. \& Loan Ass'n, 69 Cal.2d 850, 447 P.2d 609, 73 Cal. Rptr. 369 (1968) (bank liability).

56. See infra notes $74 \& 86$.

57. A lender may wish to operate the debtor's business if it has an equity interest in the debtor. A discussion of when equity risk financings are investments rather than debt is beyond the scope of this Note.

58. 131 Cong. REc. S12,031 (daily ed. Sept. 24, 1985) (statement of Sen. Evans) (major objective of Superfund is to "provide an incentive to those who manage hazardous substances or are responsible for contaminated sites to avoid releases and to make the maximum effort to clean up or mitigate the effects of any such release"); id. at S12,008 (statement of Sen. Domenici) ("we must provide incentives for the Government and private parties to join together rather than litigate"); see supra note 15 and accompanying text (innocent landowner defense acts as means of creating incentives for safer waste handling and disposal). 
ment participation encompasses at a minimum activities that would lead to operator liability under the general liability scheme. To interpret the term as something less than those actions that would lead to liability as an operator would be illogical, since banks would be more susceptible to liability under the carved-out exemption than under the general liability scheme.

An examination of the legislative history ${ }^{59}$ and court interpretations of the term "operator" shows that an operator is one who is in charge of or controls the operations at a facility. In applying CERCLA, courts have held persons who were in charge of or controlled hazardous waste disposal practices liable as operators. ${ }^{\circ 0}$ Of course, these persons were not banks, but rather shareholders and executive officers of businesses that managed hazardous wastes. They had the capacity and general responsibility as executive officers to plan and implement disposal practices; naturally, they could be considered "owners or operators." Yet even with respect to a parent corporation that controlled the management and operation of its subsidiary, one court indicated that "care must be taken so that 'normal' activities of a parent with respect to its subsidiary do not automatically warrant finding the parent an owner or operator." cates that a higher standard of participation is needed before a parent corporation would be found liable as an "owner or operator" of a subsidiary's facility. The requirement for management participation of a bank should be at least as high as the participation required of a parent corporation or similar entity. The security interest exemption only makes sense

\footnotetext{
59. The legislative history states:

Operators of vessels do not include those individuals who are not totally responsible for the operation of a vessel. To fall within the definition, the individual must have assumed the full range of operational responsibility. For example, a pilot might be in charge of navigation of a vessel for a short duration, yet he does not meet the definition of "operator", since he neither mans nor supplies the vessel. In the case of a facility, an "operator" is defined to be a person who is carrying out operational functions for the owner of the facility pursuant to an appropriate agreement.
}

H.R. REP. No. 172, 96th Cong., 2d Sess., pt. 1, at 36-37, reprinted in 1980 U.S. Cone Cong. \& ADMIN. NEws 6160, 6181-82. Although the House Report distinguishes operators of vessels from operators of facilities, the essence of the meaning of "operator" is being "in charge of," "in control of," or "responsible for" the full range of operations at a vessel or facility.

60. See, e.g., New York v. Shore Realty Corp., 759 F.2d 1032, 1052 (2d Cir. 1985) (Stockholder/ corporate officer was "in charge of the operation of the facility ... and as such is an 'operator' within the meaning of GERCLA .... [A] corporate officer who controls corporate conduct and thus is an active individual participant in that conduct is liable for the torts of the corporation."); Edward Hines Lumber Co. v. Vulcan Materials Co., 685 F. Supp. 651, 657 (N.D. Ill.) (designer and builder of treatment system at site containing facility not "operator" of site; "[o]nly those who actually operate or exercise control over the facility that creates an environmental risk can be held liable [as operator] under CERCL $A$;" although defendant enjoyed right of access, occasionally was present at facility, and trained personnel to operate facility, such does not provide evidence that defendant "ever operated .. f facility or, more significantly, exercised any control over" disposal process), affd, 861 F.2d 155 (7th Cir. 1988); United States v. Northeastern Pharmaceutical \& Chem. Co., 579 F. Supp. 823, 848-49 (W.D. Mo. 1984) (president and vice president who were also major stockholders of firm were "in charge" of plant), aff'd in part, rev'd in part, 810 F.2d 726 (8th Cir. 1986), cert. denied, 108 S. Ct. 146 (1987).

61. Idaho v. Bunker Hill Co., 635 F. Supp. 665, 672 (D. Idaho 1986). 
if management participation is not construed literally to mean participation in any management activity, but held to at least the same standard of "being in charge" or "in control" that would lead to "operator" liability under the general liability scheme.

A standard of total control would not likely decrease a bank's incentive to investigate sites prior to lending; ${ }^{62}$ instead, it would encourage banks to monitor the debtor's hazardous waste activities during the loan. ${ }^{63}$ Nevertheless, because a standard of total domination might decrease a bank's incentive to investigate before lending, courts could condition application of commercial law standards to determine lender liability upon a showing of pre-loan environmental due diligence.

Courts may find it difficult to interpret "participating in the management" as total control given the phrase's broad connotations when read literally. While Congress could help matters by clarifying the term through amendment, such action is unlikely. Instead, the EPA could issue an interpretative rule that recognizes the importance of bank monitoring of hazardous waste sites, and that supports a cumulative approach for determining whether the lender controlled the debtor. ${ }^{64}$

A cumulative approach that looks to total control is preferable to a bright-line test, since it provides courts with flexibility to address the circumstances of each case. Cumulative behavior analysis can be performed by applying the standards currently employed under the equitable subordination and alter ego theories of lender liability to determine when lenders have overreached in protecting their security interests. Although this approach is flexible, it still provides predictability because courts have applied consistently these commercial law standards of lender liability.

\section{Equitable Subordination}

Bankruptcy courts, as courts of equity, have used subordination ${ }^{65}$ as an equitable remedy against fraud and breach of fiduciary duties owed to a

62. A bank's incentive to extend credit is inversely related to the need to monitor during the loan term. The borrower, however, has an incentive to increase the riskiness of the loan after the interest rate has been set by banks, since, by doing so, "he effectively obtains a higher-risk loan at an interest rate reflecting the lower risk level anticipated by the creditor when the loan was made." Jackson \& Kronman, supra note 40 , at 1149 . Banks cannot always predict before lending how debtors may behave during the loan term. Thus, they will monitor debtors' operations to prevent misbehavior and to protect their security interests until monitoring costs exceed the possible increase in risk.

63. While a standard of total control could encourage lenders to help revive debtors by extending funds for cleanup and to allow for later recovery, not all banks are good Samaritans, nor does CERCLA, as it stands now, require them to be. See United States v. Mirabile, 15 Envtl. L. Rep. (Envtl. L. Inst.) 20,994, 20,997 (E.D. Pa. 1985) (nothing under CERCLA suggests that lenders are obligated to advance funds for purpose of cleanup, or to ensure that loan proceeds are applied to cleanup costs).

64. While interpretative rules do not bind courts, they "do constitute a body of experience and informed judgment to which courts and litigants may properly resort for guidance." Skidmore v. Swift \& Co., 323 U.S. 134, 140 (1944).

65. Under bankruptcy's priority scheme, subordination is the act or process by which the claims of the misbehaving creditor are ranked below the claims of those creditors that were disadvantaged by the misbehaving creditor's inequitable conduct. See 3 Collier on BANkruptcy If 510.05 (L. King 
bankrupt corporation. ${ }^{68}$ To order the subordination of claims, the court must find that (1) the claimant engaged in inequitable conduct, and (2) the misconduct resulted in injury to the bankrupt's creditors or conferred an unfair advantage on the claimant. ${ }^{67}$ This two-pronged standard has been referred to as the "Mobile Steel test."

The type of alleged inequitable conduct found in subordination cases usually involves either fraud or breach of a fiduciary duty owed to the bankrupt corporation. ${ }^{69}$ The doctrine is not limited to fiduciaries who are shareholders, officers, and directors of bankrupt companies, but applies to any person who acted in a fiduciary capacity, breached a fiduciary duty, and caused claimants to whom a duty was owed to suffer to their detriment. ${ }^{70}$ Because a creditor is not ordinarily a fiduciary of either his debtor or his fellow creditors, the standard of misconduct for a non-insider creditor that must be demonstrated to justify subordination is quite substantial..$^{71}$

A creditor may be considered a fiduciary of his debtor and be held accountable for his actions if he exercises control over the debtor's decisionmaking processes that amounts to domination of the debtor's will. ${ }^{72}$ Commentators have classified degrees of lender control into categories of voting control, management control, and financial domination to indicate the circumstances that have and have not led to subordination. ${ }^{73}$ While financial domination does not lead to a finding of control, voting control and management control may warrant subordination if the creditor exercises that control to the point where the debtor can make no independent decisions. ${ }^{74}$ This Note proposes that courts examine the kinds of behavior that

15th ed. 1979 \& Supp. 1988).

66. Equitable subordination was first recognized in Pepper v. Litton, 308 U.S. 295 (1939) (wage claims of dominant shareholder subordinated to claims of disadvantaged corporate creditor).

67. Benjamin v. Diamond (In re Mobile Steel Co.), 563 F.2d 692, 700 (5th Cir. 1977). The claims may be equitably subordinated only to the extent necessary to offset any unfair advantage or harm suffered on account of inequitable conduct. Id. at 701.

68. The test was codified in the Bankruptcy Reform Act, Pub. L. No. 95-598, 92 Stat. 2549, 2586 (1978) (codified as amended at 11 U.S.C. § 510(c) (1982)).

69. Persons in control of a corporation owe fiduciary duties to their corporation and possibly to other shareholders, since they are in positions of trust. Fiduciaries owe "undivided loyalty," and must act honestly and in good faith for the corporation's benefit. H. HENN \& J. ALEXANDER, LAwS OF Corporations AND OTHER Business ENTERPRises § 235, at 625-28 (3d ed. 1983).

70. In re W.T. Grant Co., 4 Bankr. 53, 74 (Bankr. S.D.N.Y. 1980), affd sub nom. Cosoff v. Rodman, 20 Bankr. 186 (S.D.N.Y. 1982), affd, 699 F.2d 599 (2d Cir.), cert. denied, 464 U.S. 822 (1983).

71. 4 Bankr. at 74-75. This Note focuses on fiduciary duty, not fraud, on the part of nonmanagement creditors.

72. See Anaconda-Ericsson, Inc. v. Hessen (In re Teltronics Serv., Inc.), 29 Bankr. 139, 170 (Bankr. E.D.N.Y. 1983).

73. See, e.g., Douglas-Hamilton, When are Creditors in Control of Debtor Companies?, PrAc. LAw., Oct. 15, 1980, at 61; Note, supra note 55, at 821-22.

74. The doctrine may be viewed as imprecise because courts have employed a "cumulative test" approach. See, e.g., In re Beverages Int'l Ltd., 50 Bankr. 273, 284-85 (Bankr. D. Mass. 1985) (cumulative weight of evidence supported finding of impropriety); 124 CoNG. REC. H32,398 (daily ed. Sept. 28, 1978) (statement of Rep. Edwards) (Congress recognized need for flexibility in applying 
have been considered "inequitable conduct" to meet the first element of the Mobile Steel test in interpreting management participation under CERGLA. ${ }^{75}$

\section{Financial Domination}

Courts have found that lenders exercising financial domination ${ }^{76}$ over a debtor have not engaged in inequitable conduct so as to warrant subordination of their claims. Financial domination ordinarily does not elevate the lender to "insider" status because the right to control the debtor financially is inherent in most debtor-creditor relationships. Illustrations of financial domination include offering business advice and insisting on its implementation, exercising daily monitoring activities, and exacting debtor concessions. ${ }^{77}$ Accordingly, banks lending to waste disposal firms should be free to perform these kinds of monitoring activities to protect their collateral. They should be free to offer suggestions to improve the safety of debtors' disposal practices, threaten to declare defaults if debtors engage in

doctrine to enable courts to deal appropriately with inequitable or fraudulent conduct, and left to courts development of principle of equitable subordination). Although the doctrine does not provide complete certainty, it does provide a sophisticated analysis to determine excessive control by focusing on the lender's cumulative behavior to see whether the lender completely dominated the policy and business practices of the debtor. See, e.g., DeNatale \& Abram, The Doctrine of Equitable Subordination as Applied to Nonmanagement Creditors, 40 Bus. LAw. 417, 429 (1985) (application of equitable subordination to claims of nonmanagement creditors has not resulted in abuse of flexibility). Also, subordination cases present consistent fact patterns of activities that have not led to a finding of control. Id. at 444-45 (creditor given broad license to monitor debtor's activities before being deemed in control).

75. Because harm to third parties is not required to trigger CERCLA liability, see supra note 4 and accompanying text (liability under CERCLA determined by whether defendant falls within class of potentially responsible parties and whether certain conditions are met), the second element-injury to other claimants-is unnecessary. The doctrine of equitable subordination requires the second element of the Mobile Steel test because bankruptcy law involves ranking of payments among creditors. When a bankruptcy court finds that a creditor has acted unfairly by improving his position vis-à-vis other claimants pre-bankruptcy, the court will subordinate his claim to those claimants who were disadvantaged. See 3 CollLIER ON BANKRUPTCX, supra note 65, I 510.05 .

76. Financial domination is the power to influence those who have voting or management control of the debtor by suggesting ways in which the debtor can improve its financial performance. DouglasHamilton, Creditor Liabilities Resulting from Improper Interference with the Management of a Financially Troubled Debtor, 31 Bus. LAw. 343, 345 (1975); Note, supra note 55, at 822.

77. For example, the court in In re W.T. Grant Co., 4 Bankr. 53, 75 (Bankr. S.D.N.Y. 1980), held that a creditor would not be subject to equitable subordination if it exercises a significant degree of daily monitoring, goes to lengths to aid a debtor, and tries to help the debtor keep intact his business so long as no other creditors are harmed. The court reasoned that equitable subordination was an extraordinary remedy, to be used sparingly, and the burden of proof was substantial, particularly with respect to non-insiders. Id. at 74-75. See also Zimmerman v. Central Penn Nat'l Bank (In re Ludwig Honold Mfg. Co.), 46 Bankr. 125, 129 (Bankr. E.D. Pa. 1985) (creditor that monitored debtor's finances on daily basis and threatened to declare default did not behave in fiduciary capacity); Bank of New Richmond v. Production Credit Ass'n (In re Osborne), 42 Bankr. 988, 997 (W.D. Wis. 1984) (that secured creditor gave debtor directions on how to spend loan funds did not give rise to control that would justify subordination); Anaconda-Ericsson, Inc. v. Hessen (In re Teltronics Servs., Inc.), 29 Bankr. 139, 172 (Bankr. E.D.N.Y. 1983) (loan agreements requiring debtor to purchase equipment from creditor and restricting outside secured financing were entered into at arm's length; lender's imposition of C.O.D. payment terms, refusal to provide additional guaranteed financing, and input into debtor's budgetary matters stemmed from sound business judgment and were within debtorcreditor relationship). 
illegal disposal practices or fail to correct risky ones, and demand that loan proceeds be spent on waste reduction equipment. By allowing lenders to influence policies or business practices in this way, courts can encourage lenders to monitor the waste sites of their debtors.

\section{Management Control}

In applying the doctrine of equitable subordination, courts may find that a lender engaged in inequitable conduct if it exercised management control ${ }^{78}$ that amounted to total domination of the debtor. ${ }^{79}$ Thus, under GERGLA, a lender would have engaged in inequitable conduct if it indirectly controlled the borrower's disposal policies and practices by hiring and firing the company's directors, dictating who would be its officers or employees, or exercising veto powers over its business decisions. For example, one court has applied equitable subordination when a bank's decisions forced the execution of security agreements in inventory and equipment; determined which of the debtor's creditors would be paid with an eye towards enhancing previously existing security interests; compelled the termination of employees; cut officer salaries; and failed to honor payroll checks. ${ }^{80}$ On the other hand, the injection of bank personnel or consultants into the debtor company to assist in its affairs will not give rise to a fiduciary relationship without a showing of undue influence or coercion. ${ }^{81} \mathrm{~A}$ bank also may exercise leverage over the debtor's business operations to restore the firm's profitability if the bank's demands are not forced upon the debtor. ${ }^{82}$ Because loan covenants can grant lenders an extensive degree of management control, courts should focus on whether the control was actually exercised and amounted to improper coercion. ${ }^{83}$

78. Management control is financial domination plus indirect control of the debtor that imposes a fiduciary standard of conduct on the bank. Illustrations of indirect control include supervising the dayto-day operations of the debtor, controlling the debtor's assets, and injecting management consultants or bank personnel into the debtor company.

79. Management control in itself is not improper if the creditor uses that control to help an ailing company become financially stable. See Soriano \& Lockett, supra note 34, at 59 (lender often appoints consultant to assist financially distressed borrower in managing affairs, requests debtor to hire new management, and suggests ways to improve operations and cut costs as part of normal workout procedures between creditor and debtor). The inequity lies in management control that is coercive and that interferes with the debtor's autonomy.

80. Bergquist v. First Nat'l Bank of St. Paul (In re American Lumber Co.), 5 Bankr. 470, 478 (D. Minn. 1980).

81. Harris Trust \& Savings Bank v. Keig (In re Prima Co.), 98 F.2d 952, 964-65 (7th Cir. 1938), cert. denied, 305 U.S. 658 (1939). Prima does not involve equitable subordination, but addresses the level of control a creditor must exercise to subject itself to a fiduciary standard of review.

82. In re Technology for Energy Corp., 56 Bankr. 307, 313-17 (Bankr. E.D. Tenn. 1985) (lender's conduct not inequitable, since bank did not control debtor's contract, personnel, production schedule, or purchase order decisions; lockbox agreement not sufficient to establish control; debtor still scheduled and established priorities of accounts payable; consultant not needlessly thrust upon debtor; bank did not control newly appointed CEO; and debtor had legal counsel throughout debtor-creditor relationship).

83. See, e.g., Fruehauf Corp. v. T.E. Mercer Trucking Co. (In re T.E. Mercer Trucking Co.), 16 Bankr. 176, 189-90 (Bankr. N.D. Tex. 1981) (loan covenants merely suggested that debtors were 
A lender should be encouraged to use its leverage to encourage workouts and to restore the profitable operations of the debtor, rather than to resort immediately to its right to declare a default. If a lender can engage in workout procedures without fear of being deemed an operator under GERCLA, it may postpone default declaration and recommend consultants to help the debtor manage finances. Neither the lender nor the bank agent benefits by cutting the debtor's operating costs to the point where disposal practices are risky, since the lender may lose the value of the security interest if a release occurs. ${ }^{84}$ Banks, then, can help debtors solve financial problems before those problems lead to risky disposal practices. Courts can encourage banks to monitor hazardous waste sites by interpreting management participation as total domination of their debtors, rather than focusing on individual activities related to management in which banks or their agents engaged.

\section{Voting Control}

Courts may find the lender in direct control of the debtor for purposes of equitable subordination if it exercised its voting power through a pledge of stock to elect directors who shape and implement the debtor's policies. ${ }^{85}$ Potential voting control is relevant under CERCLA because a bank may hold as collateral a pledge of stock of a debtor that handles hazardous wastes. As a pledgee, however, the lender does not have an automatic right to vote the stock; its right to vote is contingent upon default. Thus, potential voting power should not give rise to liability as an "owner or operator" of the debtor.

\section{Alter Ego}

Cases applying the alter ego doctrine to debtor-creditor relationships also provide guidance for determining the bounds of appropriate lender behavior under GERCLA ${ }^{88}$ Courts may invoke the equitable remedy of

instrumentalities of creditor; further evidentiary hearings necessary to discover whether creditor exercised right of control).

84. See supra note 16 (describing problems lenders could face if they held an interest in contaminated collateral).

85. Compare Unsecured Creditors' Comms. of Pacific Express, Inc. v. Pioneer Commercial Funding Corp. (In re Pacific Express, Inc.), 69 Bankr. 112, 117-18 (Bankr. 9th Cir. 1986) (loan participants holding $65 \%$ of debtor's stock pursuant to "equity sweetener" of loan agreement did not have sufficient control over debtor to be fiduciaries) and In re Technology, $56 \mathrm{Bankr}$. 307, 316 (Bankr. E.D. Tenn. 1985) (lender attained voting control as pledgee of stock, but never exercised that control) with In re Process-Manz Press, Inc., 236 F. Supp. 333, 348 (N.D. Ill. 1964) (bankrupt was alter ego of creditor through latter's holding of $90 \%$ of debtor's stock and control of income; creditor was in substance bankrupt's owner and used power to make transactions that disadvantaged other creditors), rev'd on other grounds, 369 F.2d 513 (7th Cir. 1966), cert. denied, 386 U.S. 957 (1967).

86. Although the doctrine of alter ego does not offer bright lines to determine permissible lender activities, it-like the doctrine of equitable subordination-does provide a sophisticated analysis to find excessive control based on total domination of the debtor.

The degree of control needed to substantiate an alter ego claim is high, and courts accordingly have 
alter ego if they find that the dominant corporation, usually the parent firm, (1) controlled the subservient one, and (2) proximately caused the plaintiff harm through misuse of that control. ${ }^{87}$ In cases involving alleged alter ego in debtor-creditor relationships, actual, total control is necessary to meet the first element of the test. ${ }^{88}$ Thus, the two-pronged test under alter ego resembles the two-part standard of Mobile Steel. Moreover, both tests require total domination of the debtor to trigger a finding of improper control. ${ }^{89}$ As with the analysis of equitable subordination cases to determine lender management participation under GERCLA, courts referring to the alter ego doctrine need only examine the standards developed to find whether the test's first element-total domination-is met. ${ }^{90}$

Cases applying the doctrine of alter ego support the argument that financial domination should not lead to a finding of excessive control to hold the creditor liable for the debtor's obligations. ${ }^{91}$ The cases also strengthen the proposition that management control is proper short of coercion. For example, courts have required "actual, operative, total control"92 or total surrender of debtors' management control ${ }^{93}$ for lenders to be liable under the instrumentality theory. These cases show that a higher

been reluctant to impose liability under this theory. See Lundgren, Liability of a Creditor in a Control Relationship with Its Debtor, 67 MARQ. L. REv. 523, 533 (1984) ("courts recognize the practical necessities that arise when creditors are confronted with debtors in financial distress" and may feel "it is worthwhile to permit creditors to take relatively strong measures . . . to protect the creditor's debt rather than adopt a rule which would have the effect of forcing creditors to seek premature liquidation or bankruptcy proceedings"). Similarly, courts in equitable subordination cases have given lenders broad license to monitor the activities of their borrowers before they are deemed to be in control. See supra note 74.

87. Krivo Indus. Supply Co. v. National Distillers \& Chem. Corp., 483 F.2d 1098, 1103 (5th Cir. 1973).

88. Id. at 1105 .

89. With respect to voting control, alter ego requires more than outright stock ownership to trigger liability. This requirement is logical because the dominating company, often the parent, owns stock in the subsidiary. See, e.g., Owl Fumigating Corp. v. California Cyanide Co., 30 F.2d 812 (3d Cir. 1929) (loan, stock ownership, and identity of officers do not establish identity of corporations). When the doctrine is applied to a non-management creditor, not mere ownership but unrestricted ownership of the debtor's stock is required as indicia of control of the debtor. See Riquelme Valdes v. Leisure Resource Group, Inc., 810 F.2d 1345 (5th Cir. 1987) (lender's 100\% ownership of debtor stock was not sine qua non of alter ego status, as stock was committed to escrow agent, and lender was prevented from exercising prerogatives of stock ownership pursuant to agreement).

90. Because harm to third parties is not a prerequisite to CERCLA liability, the proposed test eliminates the need to place blame that is required in the alter ego context, and looks solely at overreaching lender actions.

91. See Krivo, 483 F.2d at 1107-12 (creditor not liable under alter ego; capacity to exert great pressure and influence on debtor inherent in creditor-debtor relationship).

92. Id. at 1109; see also Riquelme Valdes, $810 \mathrm{~F} .2 \mathrm{~d}$ at 1355 (lockbox account for receivables not ipso facto proof of control over debtor; veto power in limited sense does not amount to domination); Chicago Mill \& Lumber Co. v. Boatman's Bank, 234 F. 41 (8th Cir. 1916) (bank's holding of pledge of debtor's stock and installation of agent as president of debtor are part of legitimate and customary practice of keeping oversight over business, management, and operations of financially troubled debtor); James E. McFadden, Inc. v. Baltimore Contractors, Inc., 609 F. Supp. 1102 (E.D. Pa. 1985) (loan terms do not transfer total control to creditor).

93. See, e.g., Credit Managers Ass'n v. Superior Ct., 51 Cal. App. 3d 352, 124 Cal. Rptr. 242 (1975) (plaintiff, alleging that bank compelled debtor to employ bank agent as its business consultant and to surrender complete management control, had pleaded sufficient facts to state cause of action that fiduciary duty was owed and breached). 
standard of control-complete domination-is required for nonmanagement creditors than for shareholders, directors, or officers of the controlled corporation. By interpreting management participation as total control over the debtor, courts could encourage lenders to monitor sites to protect their investments and, as an incident to exercising their bargainedfor rights, to play an active role in deterring unsafe disposal practices.

\section{CONCLUSION}

Examination of the circumstances that have and have not led to lender liability under equitable subordination and alter ego can provide creditors with a clearer framework of acceptable patterns of behavior when determining the extent to which they may assist debtors that handle hazardous wastes. To determine whether the lender participated in the management of the debtor, courts should look to the kinds of behavior that have been considered "inequitable" under the first prong of the Mobile Steel test, or to "total, participatory, actual" control under the first element of the alter ego standard. Under either approach, ${ }^{94}$ the court should find that total control amounting to ownership is what exposes the creditor to liability. ${ }^{95}$ Liability should be triggered not just by nominal activities that appear to give creditors management or voting control, but rather by actual exercise of such control that amounts to coercion, and, in effect, actual ownership. To ensure that banks will continue to investigate debtor sites prior to lending, the proposed standard of liability will apply only upon a showing that the bank conducted pre-loan environmental due diligence. ${ }^{96}$

The proposed interpretation of the words "participating in the manage-

94. Either approach will suffice, since courts will be looking at a standard of total domination. See, e.g., In re Beverages Int'l Ltd., 50 Bankr. 273 (Bankr. D. Mass. 1985) (creditor's use of debtor as alter ego is sufficient inequitable conduct to warrant subordination); DeNatale \& Abram, supra note 74, at 443 (indicia of control in instrumentality cases are relevant for determining control for equitable subordination).

95. Of course, if the lender exercises its right to elect directors or to receive dividends through a holding of stock, it will be liable as the owner of the debtor. Similarly, the mortgagee in United States v. Nicolet, who is also the former controlling stockholder of the polluter, is not a typical non-insider creditor but the former parent of the polluting company. United States' Memorandum in Support of Its Second Motion for Leave to Amend Complaint at 18, United States v. Nicolet, No. 85-3060 (E.D. Pa. filed Nov. 22, 1988). As a former parent, the company may be held to a broader, more appropriate standard which looks to whether it "had the capacity ... to make decisions and implement actions and mechanisms to prevent and abate the damage caused by the disposal and releases of hazardous wastes at the facility." Idaho v. Bunker Hill Co., 635 F. Supp. 665, 672 (D. Idaho 1986) (emphasis added).

96. The kinds of activities that have been considered proper and improper under equitable subordination and alter ego support the factual findings made by the court in United States v. Mirabile, 15 Envtl. L. Rep. (Envtl. L. Inst.) 20,994 (E.D. Pa. 1985). For example, the activities of the foreclosing mortgagee that were regarded as prudent and routine steps to secure the property, see supra note 31 and accompanying text, are illustrations of financial control under the doctrines of equitable subordination and alter ego. The activities of the secured creditor whose motion for summary judgment was denied are consistent with those described as management control under these doctrines. Moreover, the denial of summary judgment supports the proposed standard's argument that a finding of control that rivals ownership is needed to trigger liability, and that activities that appear to comprise management participation are not sufficient in themselves to warrant such a finding. 
ment" in CERCLA's security interest exemption will provide certainty and encourage efficient bank monitoring by holding lenders liable as operators only if they totally dominated the debtor's business practices. Policy objectives under CERCLA demand this interpretation because it will encourage lenders to monitor their debtors' sites. Monitoring will serve the dual purposes of protecting the lenders' investments and bargained-for rights, and promoting CERCLA's policy goals, as lenders can detect potential financial problems that may lead to risky disposal practices and help solve those problems before releases or threatened releases of hazardous substances occur. An interpretation of management participation as total domination that amounts to ownership, thereby making bank exposure to liability minimal, will encourage lenders to monitor during the loan term, maintain the debtors' enterprises as going concerns, extend the capital needed to clean up sites or install anti-pollution measures, and recover the debt when their borrowers' economic and environmental health is more stable. 